\title{
Altered characteristics of silica nanoparticles in bovine and human serum: the importance of nanomaterial characterization prior to its toxicological evaluation
}

\author{
Emilia Izak-Nau ${ }^{1,2^{*}}$, Matthias Voetz ${ }^{1}$, Stefanie Eiden ${ }^{1}$, Albert Duschl ${ }^{2}$ and Victor F Puntes ${ }^{3^{*}}$
}

\begin{abstract}
Background: Many toxicological studies on silica nanoparticles (NPs) have been reported, however, the literature often shows various conclusions concerning the same material. This is mainly due to a lack of sufficient NPs characterization as synthesized as well as in operando. Many characteristics of NPs may be affected by the chemistry of their surroundings and the presence of inorganic and biological moieties. Consequently, understanding the behavior of NPs at the time of toxicological assay may play a crucial role in the interpretation of its results. The present study examines changes in properties of differently functionalized fluorescent $50 \mathrm{~nm}$ silica NPs in a variety of environments and assesses their ability to absorb proteins from cell culture medium containing either bovine or human serum.

Methods: The colloidal stability depending on surface functionalization of NPs, their concentration and time of exposure was investigated in water, standard biological buffers, and cell culture media by dynamic light scattering (DLS), zeta potential measurements and transmission electron microscopy (TEM). Interactions of the particles with biological media were investigated by sodium dodecyl sulfate polyacrylamide gel electrophoresis (SDS-PAGE) in bovine and human serum, and extracted proteins were assessed using matrix-assisted laser desorption/ionization-time of flight technique (MALDI-TOF).
\end{abstract}

Results: It was recognized that all of the studied silica NPs tended to agglomerate after relatively short time in buffers and biological media. The agglomeration depended not only on the NPs functionalization but also on their concentration and the incubation time. Agglomeration was much diminished in a medium containing serum. The protein corona formation depended on time and functionalization of NP, and varied significantly in different types of serum.

Conclusions: Surface charge, ionic strength and biological molecules alter the properties of silica NPs and potentially affect their biological effects. The NPs surface in bovine serum and in human serum varies significantly, and it changes with incubation time. Consequently, the human serum, rather than the animal serum, should be used while conducting in vitro or in vivo studies concerning humans. Moreover, there is a need to pre-incubate NPs in the serum to control the composition of the bio-nano-composite that would be present in the human body.

Keywords: Nanocharacterization, Protein corona, Silica nanoparticles, Stability

\footnotetext{
*Correspondence: emilia.izak@bayer.com; victor.puntes@icn.cat

'Bayer Technology Services GmbH, Leverkusen 51368, Germany

${ }^{3}$ Catalan Institute of Nanotechnology (ICN), Campus UAB, Edifici CIN2,

Barcelona 08193, Bellaterra, Spain

Full list of author information is available at the end of the article
} 


\section{Background}

Nanoparticles (NPs) exhibit a variety of unique chemical and physical properties that have made them central components in an array of emerging technologies. Among various NPs that have found commercial application, silica $\mathrm{NPs}\left(\mathrm{SiO}_{2} \mathrm{NPs}\right)$ are rapidly becoming a part of our daily life. They are produced on an industrial scale as additives to cosmetics, drugs, printer toners and foods. Functionalized $\mathrm{SiO}_{2}$ NPs are being applied in biotechnology and biomedicine as drug delivery systems, in cancer therapy, for enzyme immobilization and for DNA transfection [1-11]. This is in part due to the simplicity of tailoring their surface reactivity via surface functionalization $[12,13]$. They can also be easily co-synthesized with a variety of fluorophores, in order to produce robust, fluorescent NPs [14].

However, the unique physicochemical properties of $\mathrm{SiO}_{2}$ NPs that have made them attractive for the industry may bring potential hazards to human health. Hence, toxicological studies on $\mathrm{SiO}_{2}$ NPs have been initiated. $\mathrm{SiO}_{2}$ NPs which are available on the market are never pristine particles; they are usually functionalized for their specific application. They can be positively or negatively charged, or have 'neutral surface'. They can be monodispersed or aggregated. They may be contaminated, what can affect results of their toxicity tests. Consequently, the information about the particles state, in other words, their proper physicochemical characterization prior to their toxicological evaluation seems to be crucial. Moreover, many NPs are likely to undergo significant size distribution or surface chemistry changes while transferred into different environments used for in vitro and in vivo biological studies $[15,16]$. Particles may aggregate due to ionic strength of physiological buffers or chemical reactions with molecules derived from the cell culture media [15-20]. Furthermore, the surface properties of the particles can also differ due to adsorption of proteins and reactions of stabilizing groups [21-24]. When NPs enter a biological fluid, proteins and other biomolecules rapidly compete for binding to the NP surface, leading to a formation of a dynamic protein layer that critically defines the biological identity of the particle [25-38]. It is believed that within the first seconds or minutes after immersion of NPs into biological fluids a soft protein corona (PC) is formed and subsequently evolves into a hard PC within hours $[39,40]$. That may consequently change the NPs properties, affecting biological responses and NPs biodistribution. Thus, the properties of the nano-system, which finally interacts with cells during biological tests, may differ from the initially characterized NPs. Consequently, understanding the NPs behavior at the time of the experiments plays a key role in the interpretation of toxicological results.

In recent years, several studies presenting NPs in different environments with influence on cell viability have been published. It has been shown that different methods of sample preparation had an impact on NPs stability and consequently on the results of toxicity tests $[41,42]$. In 2004, Rejman et al. have shown that NPs aggregation before uptake altered uptake probability and uptake mechanism and thereby affected biological response [43]. Similarly, it has also been reported that the presence of proteins in a medium affected the entry and intracellular localization of NPs within cells, and thus modulated their potential toxicity $[44,45]$. Nevertheless, while there is a great deal of studies into biological responses to pristine NPs, for differently functionalized $\mathrm{SiO}_{2} \mathrm{NPs}$, there is little information in the literature on their stability in physiological environments and on their interaction with proteins. Indeed, surface functionalized particles are most widely used in the applications of $\mathrm{SiO}_{2} \mathrm{NPs}$ and are the base of future nanotechnological developments.

The ability of NPs to adsorb proteins has already been shown to depend on the surface coating $[34,46]$. However, none of the studies until now has presented PC formation for so long time frames, especially on extensively characterized $50 \mathrm{~nm} \mathrm{SiO}_{2}$ NPs which were varied only in surface chemistry. Even more significant, none of the studies has shown differences in PC formation by comparing serum derived from animal and human.

For the purpose of this study, $50 \mathrm{~nm}$ monodispersed fluorescent core/shell $\mathrm{SiO}_{2}$ NPs were functionalized with $-\mathrm{NH}_{2},-\mathrm{SH}$ groups and coated with polyvinylpyrrolidone (PVP), and characterized using a variety of physicochemical methods including zeta potential measurements, dynamic light scattering (DLS), transmission electron microscopy (TEM), scanning electron microscopy (SEM), $\mathrm{X}$-ray photoelectron spectroscopy (XPS), secondary ion mass spectroscopy-time of flight (SIMS-TOF) and X-ray diffraction (XRD). The colloidal stability depending on their surface functionalization, concentration and time was investigated in water, standard biological buffers, and cell culture media. Interactions of the particles with biological media was investigated by sodium dodecyl sulfate polyacrylamide gel electrophoresis (SDS-PAGE) in FBS and human serum, and extracted proteins were assessed using matrix-assisted laser desorption/ionization-time of flight technique (MALDI-TOF).

\section{Results and discussion}

Amorphous $50 \mathrm{~nm} \mathrm{SiO}_{2}$ NPs encapsulating fluoresceinisothiocyanate (FITC) and functionalized with amino groups $\left(\mathrm{SiO}_{2} \_\mathrm{NH}_{2}\right)$, mercapto groups $\left(\mathrm{SiO}_{2} \_\mathrm{SH}\right)$ and polyvinylpyrrolidone $\left(\mathrm{SiO}_{2} \mathrm{PVP}\right)$ were synthesized as described previously [47]. The presence of different functional groups immobilized onto the NPs surface was monitored by zeta potential measurements, XPS and SIMS analysis. Full information about the NPs 
characterization as synthesized is shown elsewhere and the results are summarized in Table 1 [47].

All of the $\mathrm{SiO}_{2}$ NPs used in this study were well dispersed in ethanol without any agglomeration. Since many NPs characteristics, especially the state of agglomeration, can be affected by chemistry of the surroundings and the presence of both inorganic and biological moieties, understanding of NP behavior in specific environments is crucial. It has been previously shown that many NPs agglomerate in media with a high electrolyte content due to electrostatic screening effects [48], however, the presence of proteins in colloidal suspension stabilize NPs against agglomeration, even in physiological electrolyte concentrations $[37,39,49]$.

According to DLS results, properties of all studied $\mathrm{SiO}_{2}$ NPs got slightly altered when transferred from ethanol into Milli-Q (MQ) water (Figure 1-A). However, all of the examined NPs, besides the $\mathrm{SiO}_{2} \mathrm{NH}_{2}$, were stable in MQ water for at least $48 \mathrm{~h}$. Strong aggregation was observed only in case of the amino functionalized NPs already after $10 \mathrm{~min}$. The zeta potential dropped significantly from $42.2 \mathrm{mV}$ to $2.1 \mathrm{mV}$ (see Additional file 1). After $30 \mathrm{~min}$, the agglomerates were big enough to sediment, and their size was more than $1 \mu \mathrm{m}$.

In buffers and biological media the NPs are expected to behave differently than in MQ water. In these environments, the ionic strength is usually around $150 \mathrm{mM} \mathrm{NaCl}$, so the electrostatic forces are most likely screened within few nanometers of the surface. For the investigation of such an effect on the $\mathrm{SiO}_{2}$ NPs the most common buffer (PBS), and a standard cell culture medium (DMEM), with and without serum, were used. In PBS all of the particles were completely agglomerated/aggregated after $1 \mathrm{~h}$ (Figure 1-B). The $\mathrm{SiO}_{2} \mathrm{SH}$ NPs aggregated already after 10 min. In case of the $\mathrm{SiO}_{2} \mathrm{NH}_{2} \mathrm{NPs}$ the aggregation was slightly slower, nevertheless after $30 \mathrm{~min}$ the size of aggregates was more than $2 \mu \mathrm{m}$. The aggregates were generally smaller in case of the non-functionalized $\mathrm{SiO}_{2}$ NPs, however, even in this case the aggregation was already detected after $10 \mathrm{~min}$. For the $\mathrm{SiO}_{2}$ PVP NPs the rate of aggregation was much lower, showing some size increase only after $1 \mathrm{~h}$. Surface charge measurements for all of the $\mathrm{SiO}_{2} \mathrm{NPs}$ in different environments can be found in Additional file 1.

In DMEM the results were comparable to the ones obtained for PBS (Figure 1-C). The observed similarity was caused by similar ionic strength of these solutions [50]. In DMEM supplemented with 10\% FBS serum the aggregation was much diminished (Figure 1-D). However, at the studied concentration of $1 \times 10^{13} \mathrm{NPs} \mathrm{mL}^{-1}$ all of the NPs were aggregated after $48 \mathrm{~h}$. In the same time, DLS measurements indicated that decreasing concentration of the NPs decreased the rate of their aggregation (Figure 2). Kretzschmar et al. have also shown that increasing particle concentration of kaolinite resulted in faster growth of aggregates [51]. Burns et al. have found that colloidal polystyrene latex particle aggregation increased with particle concentrations at a fixed level of electrolyte [52]. However, in PBS and DMEM, even at the lowest detectable concentration $\left(1 \times 10^{10} \mathrm{NPs} \mathrm{mL}^{-1}\right)$, the NPs aggregated after $1 \mathrm{~h}$ of incubation.

In case of DMEM supplemented with 10\% FBS, the particles remained stable at a concentration of $1 \times 10^{12}$ NPs $\mathrm{mL}^{-1}$. Measurements at lower NPs concentrations could not be performed due to the higher free proteins content in the samples in comparison to the concentration of the NPs. DLS analysis detected sizes of 5-10 nm, which is the average size of the proteins in FBS. The free proteins could be removed via a centrifugation/washing/ sonication procedure. However, it was recognized that in

Table 1 Physico-chemical characterization of nanoparticles

\begin{tabular}{|c|c|c|c|c|}
\hline Name & $\mathrm{SiO}_{2}$ & $\mathrm{SiO}_{2-} \mathrm{NH}_{2}$ & $\mathrm{SiO}_{2} \mathrm{SH}$ & $\mathrm{SiO}_{2} \mathrm{PVP}$ \\
\hline Shape & TEM: spherical & & & \\
\hline Concentration & $2.0 \%(\mathrm{wt} / \mathrm{wt}) ; 1.5 \times 10^{14}$ & NPs $\mathrm{mL}^{-1}$ & & \\
\hline Crystal structure & XRD: amorphous & & & \\
\hline \multirow[t]{4}{*}{ Size/size distribution } & DLS: $58.2 \pm 2.6$ nm; & DLS: $66.0 \pm 3.3 \mathrm{~nm}$; & DLS: $61.3 \pm 3.5$ nm; & DLS: $67.6 \pm 2.6 \mathrm{~nm}$; \\
\hline & $\mathrm{PDI}[\mathrm{a}]=0.055$ & $\mathrm{PDI}=0.082$ & $\mathrm{PDI}=0.067$ & $\mathrm{PDI}=0.079$ \\
\hline & TEM: $d_{50}=50 \mathrm{~nm}$ & TEM: $d_{50}=54 \mathrm{~nm}$ & TEM: $d_{50}=56 \mathrm{~nm}$ & TEM: $d_{50}=53 \mathrm{~nm}$ \\
\hline & $\mathrm{d}_{90}=55 \mathrm{~nm}$ & $\mathrm{~d}_{90}=61 \mathrm{~nm}$ & $\mathrm{~d}_{90}=63 \mathrm{~nm}$ & $\mathrm{~d}_{90}=57 \mathrm{~nm}$ \\
\hline \multirow[t]{4}{*}{ Surface chemistry } & XPS: Atom\%: & XPS: Atom\%: & XPS: Atom\%: & XPS: Atom\%: \\
\hline & O 62.8, Si 25.6, & O 57.8, Si 24.3, & O 61.8, Si 25.6, & O 44.5, Si 33.5, \\
\hline & C 11.6 & C 16.1, N 1.8 & $C 12.6, S<1$ & C 18.0, N 3.9 \\
\hline & SIMS: $\mathrm{Si}_{x} \mathrm{O}_{y}, \mathrm{C}_{6} \mathrm{H}_{15} \mathrm{O}_{3} \mathrm{Si}$ & SIMS: $\mathrm{Si}_{x} \mathrm{O}_{\mathrm{y}}, \mathrm{F},\left(\mathrm{H}_{2} \mathrm{~N}\left(\mathrm{CH}_{2}\right)_{3} \mathrm{Si}\left(\mathrm{OC}_{2} \mathrm{H}_{5}\right)_{3}\right)$ & SIMS: $\mathrm{Si}_{x} \mathrm{O}_{y^{\prime}} \mathrm{Cl},\left(\left(\mathrm{CH}_{3} \mathrm{O}\right)_{3} \mathrm{Si}\left(\mathrm{CH}_{2}\right)_{3} \mathrm{SH}\right)$ & SIMS: $\mathrm{Si}_{x} \mathrm{O}_{y^{\prime}} \mathrm{F}_{1} \mathrm{C}_{6} \mathrm{H}_{9} \mathrm{NO}$ \\
\hline \multirow[t]{2}{*}{ Surface charge (Z-potential) } & $-41.71 \mathrm{mV} \pm 0.82$ & $+42.24 \mathrm{mV} \pm 1.49$ & - $47.73 m V \pm 0.91$ & $-40.87 m V \pm 1.31$ \\
\hline & IEP[b]: pH 3.1 & IEP: pH 6.4 & IEP: pH 1.3 & IEP: pH 4.6 \\
\hline
\end{tabular}

[a] polydispersive index; [b] isoelectric point. 

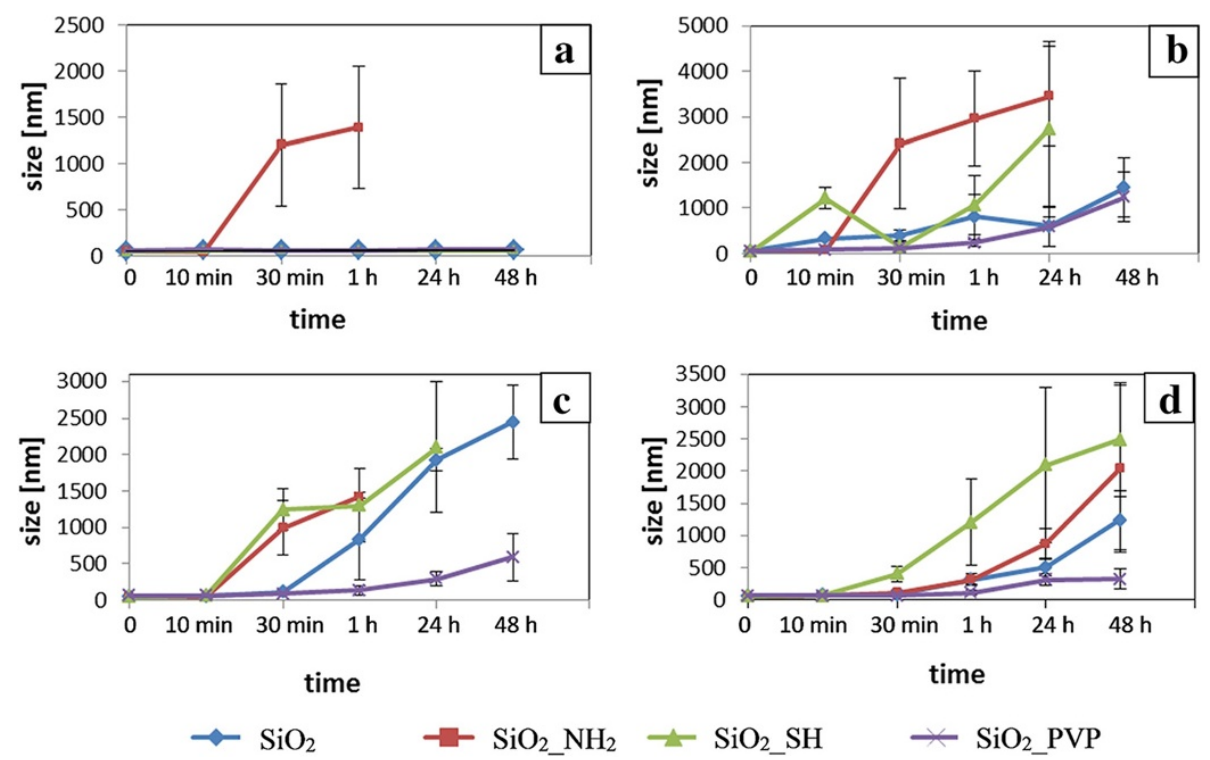

Figure 1 Time dependent silica nanoparticles stability in different environments. NPs size was measured by DLS in (a) $\mathrm{H}_{2} \mathrm{O}$, (b) PBS, (c) DMEM, (d) DMEM + 10\% FBS; NPs concentration of $1 \times 10^{13} \mathrm{NPs} \mathrm{mL}^{-1}$.

this case the particles size was different than in the case when these procedures were not applied. Too long/fast particles centrifugation, too many washing steps or too long sonication caused the aggregation of the particles. The accurate conditions for silica NPs were found at 15 min centrifugation at $8000 \times g$, one washing step with PBS and gentle NPs pipetting or $5 \mathrm{~min}$ in a sonication bath. However, when the sonication procedure was applied, in some cases the size of NPs was lower than the NPs size measured directly in DMEM supplemented with $10 \% \mathrm{FBS}$, or even the same like bare particles (without proteins), suggesting that this procedure would partially/totally destroy the formed protein corona.

Based on the results/concerns presented above, the concentration of $1 \times 10^{12} \mathrm{NPs} \mathrm{mL}^{-1}$ was found to be the

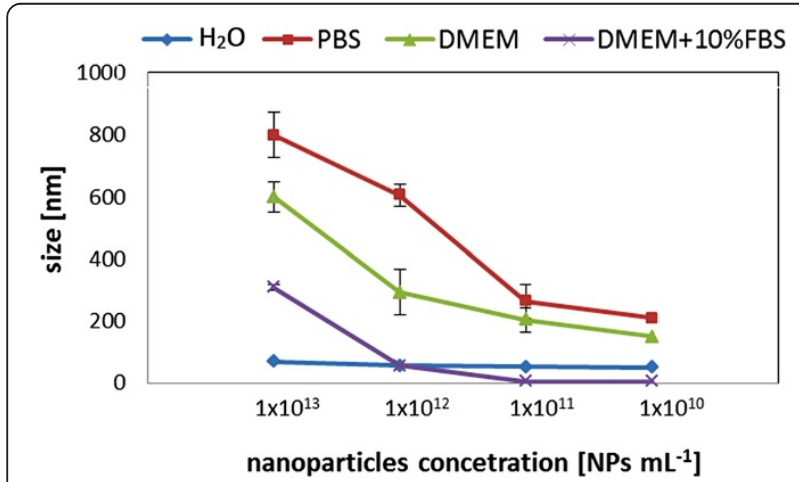

Figure 2 Concentration dependent silica nanoparticles stability in different environments. DLS measurements indicated that decreasing concentration of the NPs decreased the rate of their agglomeration. most suitable to study time dependent stability and changes in PC formation on the differently functionalized $\mathrm{SiO}_{2}$ NPs. DLS data showed that all of the examined NPs were stable at concentration of $1 \times 10^{12}$ NPs $\mathrm{mL}^{-1}$ in DMEM supplemented with $10 \%$ FBS for at least 2 weeks (Figure 3). After $48 \mathrm{~h}$ of incubation in the protein solution the particle sizes seemed to slightly rise. The zeta potential values also became more negative. In this case, it would suggest a higher stability of the nanosystem. TEM images of plain $\mathrm{SiO}_{2} \mathrm{NPs}$ after different incubation times are shown in Figure 4. A protein layer surrounded the NPs was observed after $10 \mathrm{~min}$. After $48 \mathrm{~h}$ the NPs size increased to $60 \mathrm{~nm}$, and after 2 weeks to $80 \mathrm{~nm}$. Since no NPs aggregation/sedimentation was detected during this time, this suggested that more than a single layer of proteins was immobilized onto the NPs surface, providing an effective protection against NP-NP interactions leading to aggregation. It is worth noting, that a multilayer of proteins implies protein denaturation [53]. This kind of denaturation is rarely observed and is related to a specific surface charge and hydrophobicity.

It has already been shown by Vroman, in 1962, that adsorption of blood serum proteins onto an inorganic surface was time dependent [54]. Vroman assumed that the proteins with the highest mobility attached firstly, and later were replaced by less mobile biomolecules that had a higher affinity to the surface, in a process that took several hours. Thus, the kinetics of serum protein adsorption onto differently functionalized $\mathrm{SiO}_{2} \mathrm{NPs}$ were additionally investigated in our work. The majority of in vitro and in vivo tests concerning NPs are performed 


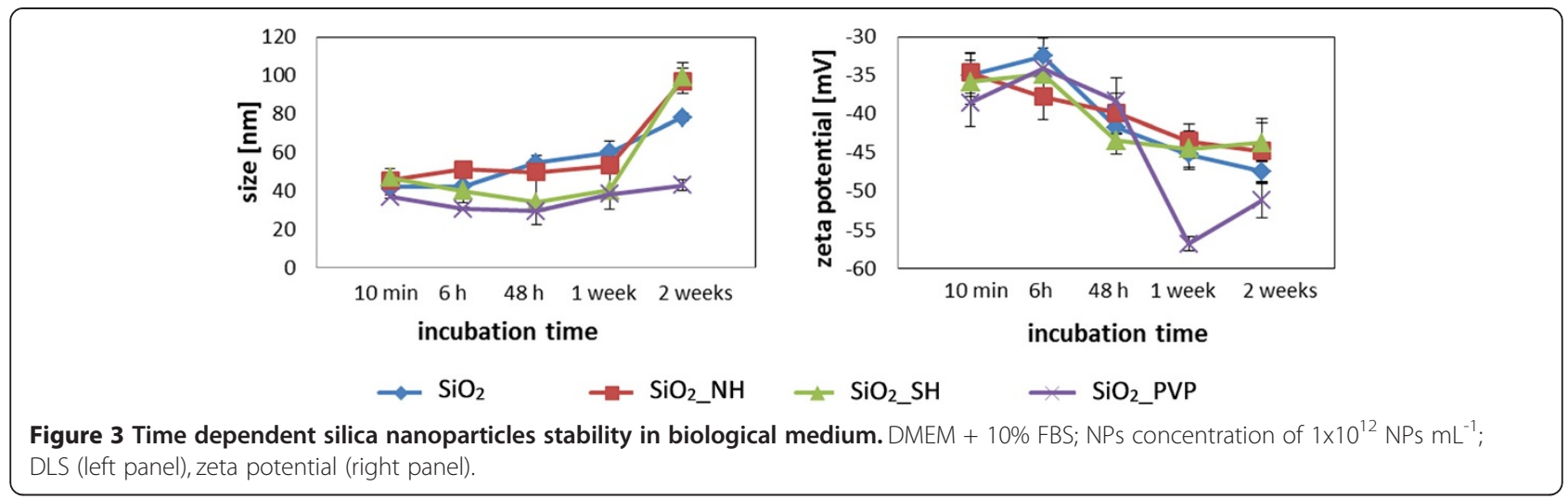

using bovine serum, mainly because of its availability and traditional use in many assays, as well as for economic reasons. Since the proteins of bovine serum differ from human proteins, the PC formation and its composition may differ as well. To study differences in proteins associations in different serum, FBS and human serum were applied.

SDS-PAGE results indicated that formation of the hard PC took much longer than it was described in the literature before (Figure 5). Previous publications $[34,40]$ have shown that the hard PC was formed after $1 \mathrm{~h}$ after NPs incubation in biological medium. In our case, there were still some changes in the hard PC observed even after $24 \mathrm{~h}$. Some slight changes in the proteins adsorption/ desorption were even visible after one week. Based on a visual evaluation of the SDS-PAGE gels, the total amounts of adsorbed protein changed not only with time but the extent of protein adsorption/desorption was also functionalization dependent. This might be one of the factors leading to diverse intracellular responses and toxicological outcomes [55]. The amount of proteins was additionally estimated by ImageJ software (Figure 6).

Figure 5 and Figure 6 show that the NPs which attracted the highest amount of FBS proteins were the plain $\mathrm{SiO}_{2}$ and the $\mathrm{SiO}_{2} \mathrm{NH}_{2}$. In the case of the plain $\mathrm{SiO}_{2} \mathrm{NPs}$, after $72 \mathrm{~h}$ incubation time and onwards, there were no significant changes in the $\mathrm{PC}$ composition. It is worth noting that, in this case, the amount of the adsorbed proteins increased after $24 \mathrm{~h}$ and stayed almost stable for one week, what is in agreement with our TEM results presented in Figure 4. However, some slight changes in the proteins adsorption/desorption were still visible after one week. In the case of the $\mathrm{SiO}_{2} \mathrm{NH}_{2}$ there were small differences observed in the PC between $24 \mathrm{~h}$

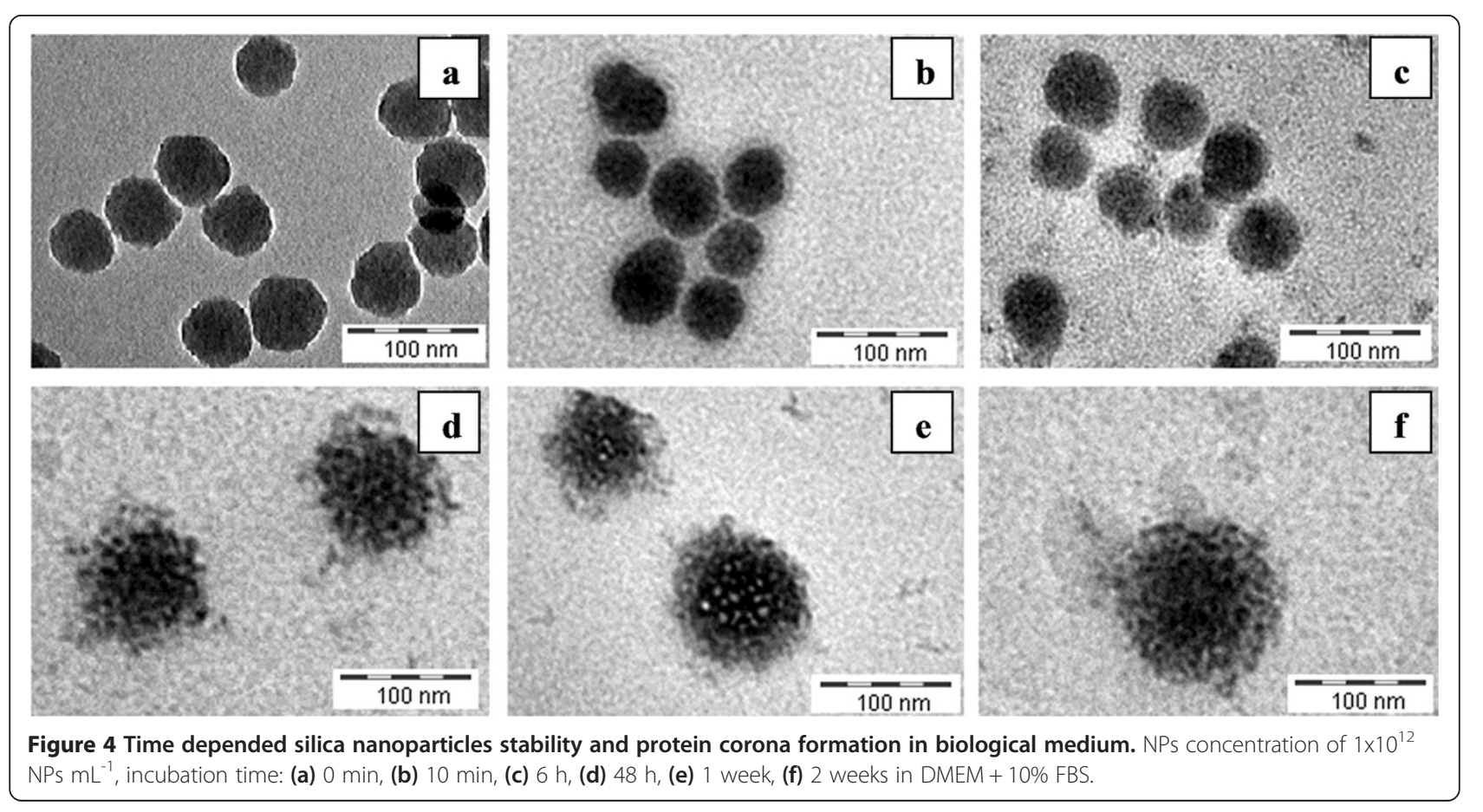




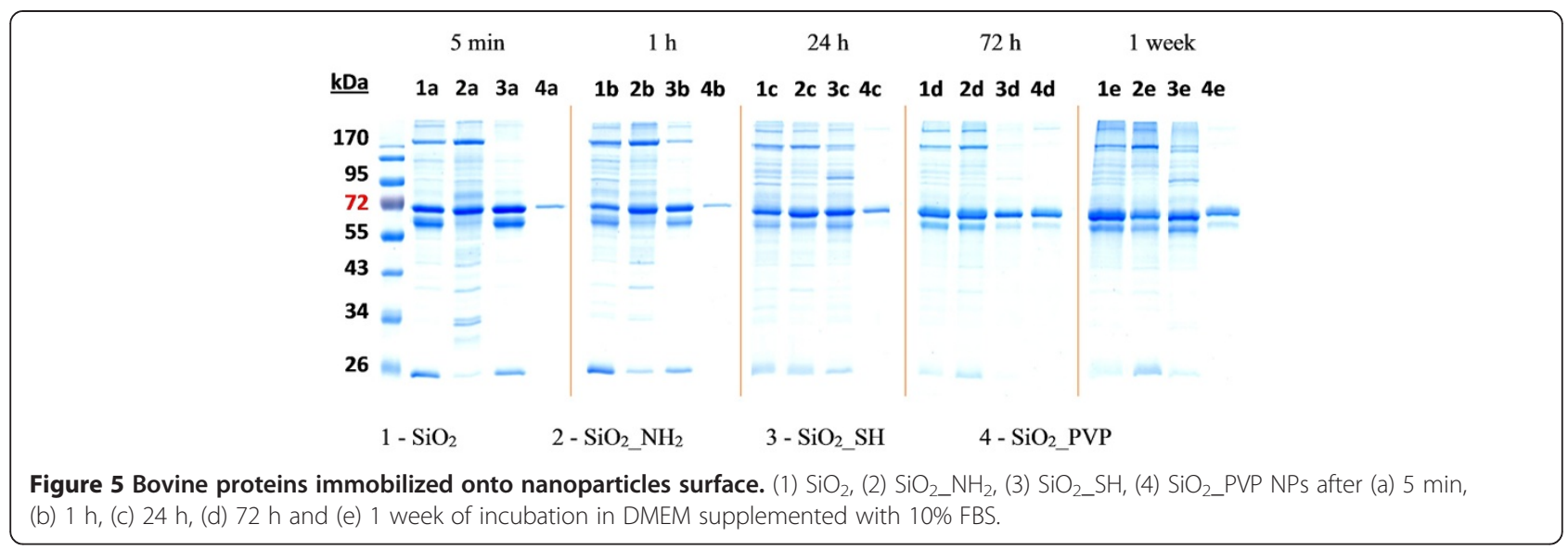

and $72 \mathrm{~h}$, while after one week the amount of bound proteins was slightly lower. On the $\mathrm{SiO}_{2} \mathrm{SH}$ after $24 \mathrm{~h}$ the amount and number of proteins increased and after $72 \mathrm{~h}$ decreased again. After one week only slight changes were detectable. The rate of protein adsorption was reduced in the case of the PVP-coated NPs, presumably due to steric repulsion.

In the case of human serum, the stabilization of the PC was much faster (Figure 7 and Figure 8). After $1 \mathrm{~h}$ the PC did not significantly differ from the $5 \mathrm{~min}$ incubation. The NPs which attracted the highest number of human proteins were the $\mathrm{SiO}_{2} \mathrm{NH}_{2}$. However, after $24 \mathrm{~h}$ the $\mathrm{PC}$ still evolved and differences between the different NPs were very small. After $72 \mathrm{~h}$, the same number and amount of proteins were identified on each NP.
In Table 2 we show all of the proteins identified with MALDI-TOF analysis, depending on incubation time and NP functionalization. The analysis indicated that, in the case of FBS, the most abundant protein, irrespective of time or functionalization, was bovine serum albumin (BSA), which is the most prevalent protein in FBS [56]. The other protein detected on every NP regardless of time was apolipoprotein A-I. Apolipoprotein E was detected on the plain $\mathrm{SiO}_{2} \mathrm{NPs}$ (after $1 \mathrm{~h}$ incubation time) and on the $\mathrm{SiO}_{2} \mathrm{NH}_{2}$ (after 24 h). On the plain $\mathrm{SiO}_{2}$ alpha 2-macroglobulin precursor was found after $72 \mathrm{~h}$, while it was also adsorbed onto the $\mathrm{SiO}_{2} \mathrm{SH}$ NPs after $24 \mathrm{~h}$. Plasminogen precursor (anticoagulant factor) was also adsorbed on the plain $\mathrm{SiO}_{2}$ NPs regardless of time, while on the $\mathrm{SiO}_{2} \mathrm{NH}_{2}$ it disappeared after 1 week, and

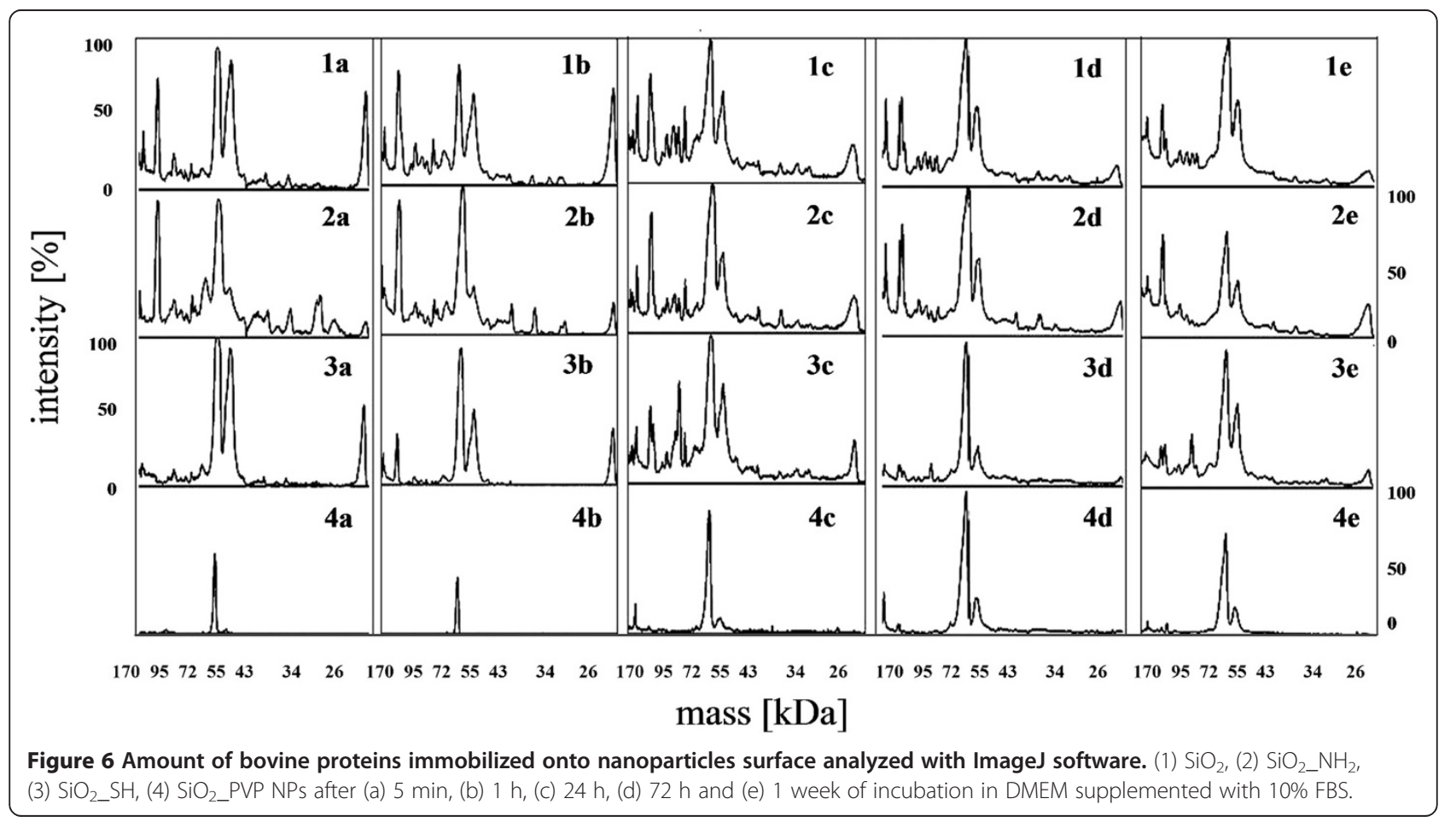




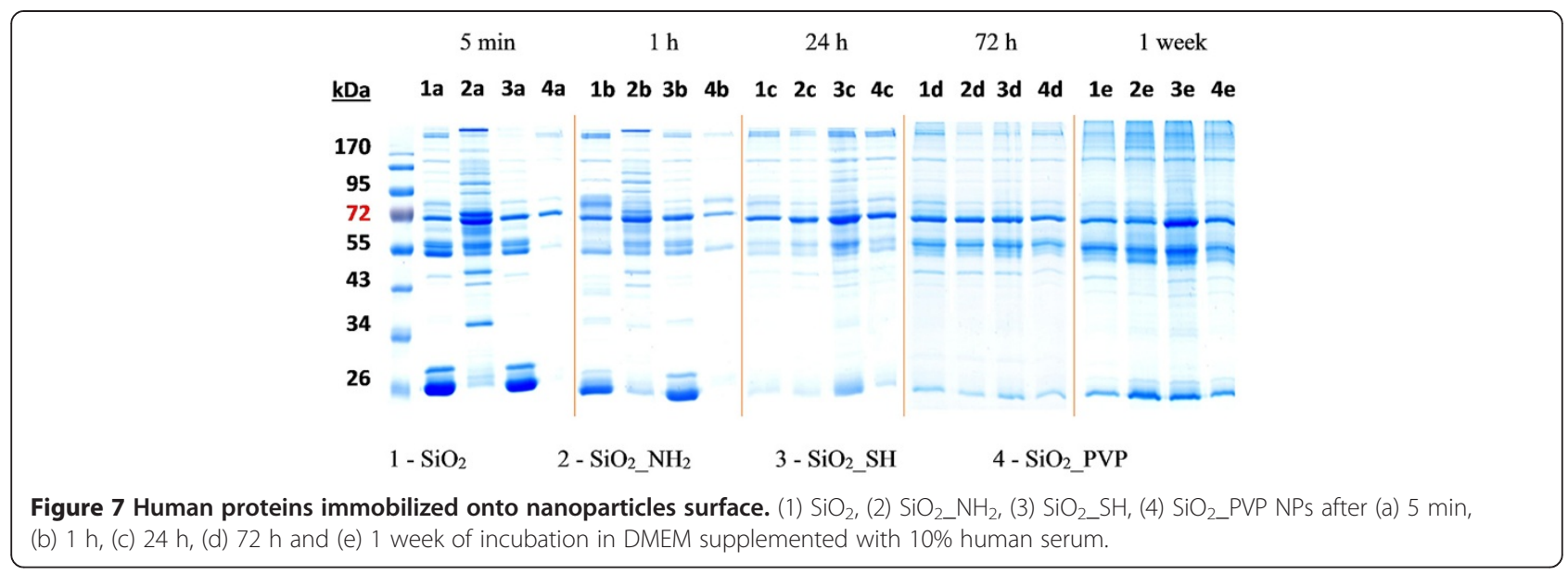

in the case of the $\mathrm{SiO}_{2} \_\mathrm{SH}$ it was only detectable after $24 \mathrm{~h}$. Gelsolin isoform b was also detected on the plain $\mathrm{SiO}_{2} \mathrm{NPs}$ at any time. On the $\mathrm{SiO}_{2} \mathrm{NH}_{2}$ it disappeared after 1 week, and in case of the $\mathrm{SiO}_{2} \mathrm{SH}$ it was detected only after $5 \mathrm{~min}, 24 \mathrm{~h}$ and 1 week. Kelch like protein 9 was adsorbed on the plain $\mathrm{SiO}_{2}$ and $\mathrm{SiO}_{2} \_\mathrm{NH}_{2}$ irrespective of time. It was also present on the surface of the $\mathrm{SiO}_{2} \mathrm{SH}$ after 1 week. Complement $\mathrm{C} 4 \mathrm{~A}$ was detected on the plain $\mathrm{SiO}_{2} \mathrm{NPs}$, the $\mathrm{SiO}_{2} \_\mathrm{NH}_{2}$ and $\mathrm{SiO}_{2} \_\mathrm{SH}$ until $24 \mathrm{~h}$ of the incubation.

In the case of human serum, the most abundant protein, irrespective of time or functionalization, was human serum albumin (HSA). Other proteins detected on every NP independent of time were apolipoprotein B-100 precursor, and an autoimmune complex between a human IgM rheumatoid factor and IgG 1. Lipid free human apolipoprotein-1 and alpha-1-antitrypsin were detected on every NP irrespective of time, on $\mathrm{SiO}_{2} \mathrm{PVP}$ they appeared after $24 \mathrm{~h}$. Complement C4-B-like preproprotein, antithrombin III and inter-alpha (globulin) inhibitor $\mathrm{H} 2 \mathrm{i}$ were adsorbed only on $\mathrm{SiO}_{2} \mathrm{NH}_{2}$ and just at $5 \mathrm{~min}$ and $1 \mathrm{~h}$. Human complement component C3c and coagulation factor II (thrombin) were adsorbed on every kind of NP after $24 \mathrm{~h}$. In the case of $\mathrm{SiO}_{2} \mathrm{NH}_{2}$ they were already detectable after $5 \mathrm{~min}$. Apolipoprotein A-IV precursor was only adsorbed at $5 \mathrm{~min}\left(\mathrm{SiO}_{2}\right.$,

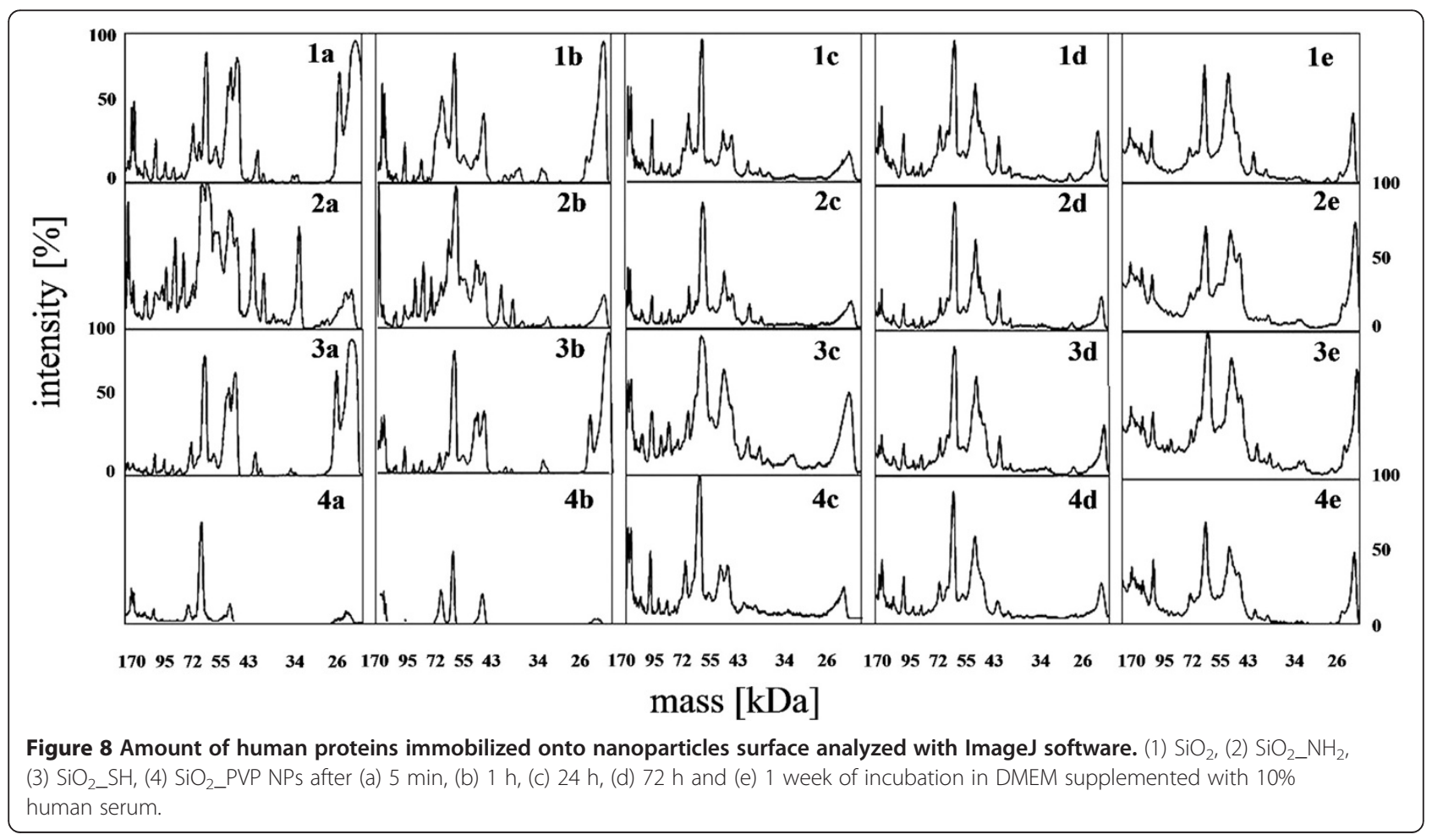


Table 2 Bovine and human proteins immobilized onto nanoparticles surface analyzed with MALDI-TOF

\begin{tabular}{|c|c|c|c|c|c|c|c|c|c|c|c|c|c|c|c|c|c|c|c|}
\hline & \multicolumn{4}{|c|}{$\mathrm{SiO}_{2}$} & \multicolumn{5}{|c|}{$\mathrm{SiO}_{2} \mathrm{NH}_{2}$} & \multicolumn{5}{|c|}{$\mathrm{SiO}_{2} \mathrm{SH}$} & \multicolumn{5}{|c|}{$\mathrm{SiO}_{2} \mathrm{PVP}$} \\
\hline 1 & 2 & 3 & 4 & 5 & 1 & 2 & 3 & 4 & 5 & 1 & 2 & 3 & 4 & 5 & 1 & 2 & 3 & 4 & 5 \\
\hline
\end{tabular}

FBS

Chain A, bovine serum albumin

Serum albumin precursor

Apolipoprotein A-I

Apolipoprotein E

Alpha-2-macroglobulin precursor

Plasminogen precursor

Gelsolin isoform b

Kelch-like protein 9

complement C4-A [a]

Human serum

Chain A, human serum albumin

Chain A, lipid-free human apolipoprotein A-I

Apolipoprotein A-IV precursor

Apolipoprotein B-100 precursor

Apolipoprotein E

Complement C4-A preproprotein

Complement C4-B-like preproprotein

Chain C, human complement component C3C

Alpha-1-antitrypsin

Chain A [b]

Coagulation factor II (thrombin)

Antithrombin III

Inter-alpha (globulin) inhibitor $\mathrm{H} 2 \mathrm{i}$

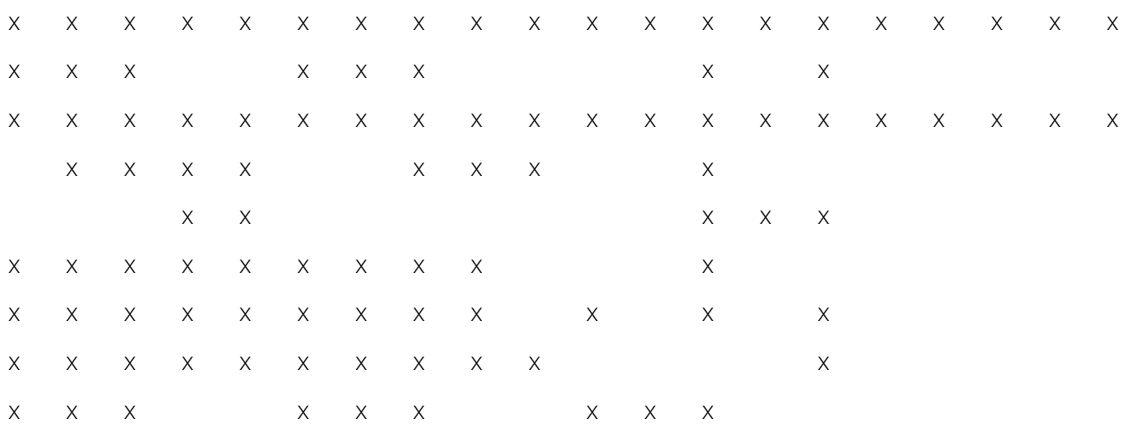

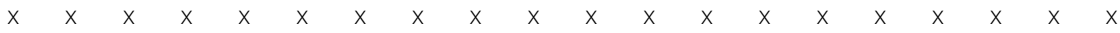

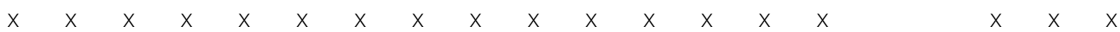

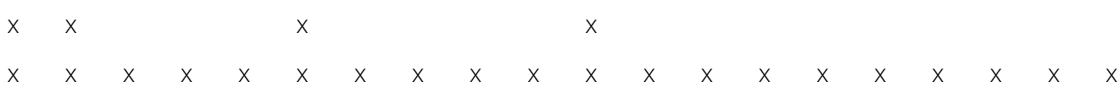

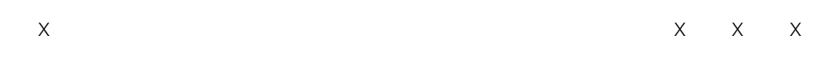

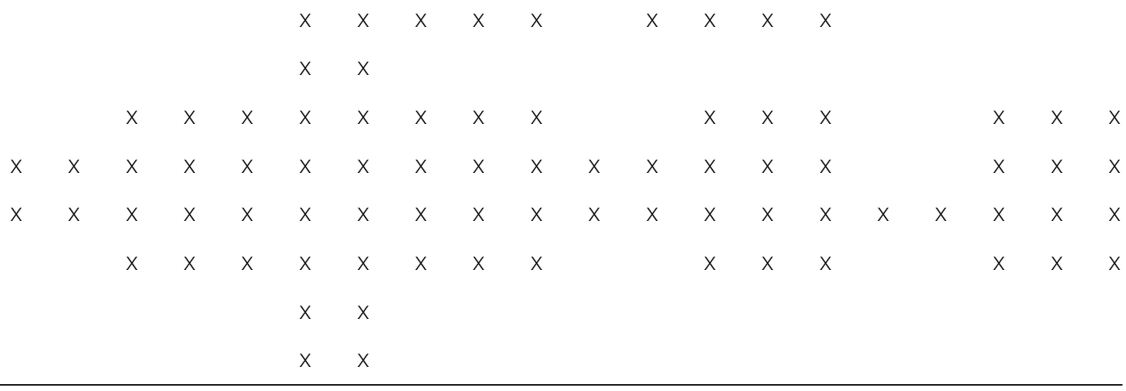

(1) 5 min, (2) 1 h, (3) 24 h, (4) 72 h, (5) 1 week of NPs incubation in DMEM supplemented with $10 \%$ serum.

[a] predicted; [b] an autoimmune complex between a human IgM rheumatoid factor and IgG1 factor reveals a novel factor epitope and evidence for affinity maturation.

$\left.\mathrm{SiO}_{2} \mathrm{NH}_{2}, \mathrm{SiO}_{2} \mathrm{SH}\right)$ and $1 \mathrm{~h}\left(\mathrm{SiO}_{2}\right)$. Complement C4-A preproprotein was detected on $\mathrm{SiO}_{2} \mathrm{NH}_{2}$ (at each time point) and $\mathrm{SiO}_{2} \mathrm{SH}$ (after $1 \mathrm{~h}$ ). Apolipoprotein $\mathrm{E}$ was attached onto the plain $\mathrm{SiO}_{2}$ NPs (only at $1 \mathrm{~h}$ ) and onto the $\mathrm{SiO}_{2} \mathrm{NH}_{2}$ (at $1 \mathrm{~h}$ and $24 \mathrm{~h}$ ).

BSA and HSA are very similar globular proteins that perform the same functions. However, BSA is composed of 582 amino acid residues while HSA of 585 . They also differ in the amino acid composition and charge (BSA: -17, HSA: -15) [57-59]. These differences may affect the conformation, and subsequently regulate proteins adsorption on the NP surface. Consequently the NP interactions with biological surfaces could differ, which may affect biological responses and NPs fate. Besides HSA, the most dominated proteins of human serum immobilized on the NPs surfaces were apolipoproteins. The apolipoproteins participate in lipids transportation in the bloodstream and, as such, are expected to affect the intracellular trafficking and transport of NPs. Apo B-100, present in the case of human serum but not in FBS, functions as a recognition signal for the cellular binding and internalization of low-density lipoproteins (LDL). Other proteins found only in the case of human serum are described below. Alpha 1-antitrypsin is a serum trypsin inhibitor; it protects tissues from enzymes of inflammatory cells. Human complement component C3c is a protein of the immune system; it plays a central role in the activation of the complement system and contributes to innate immunity. Complement $\mathrm{C} 4 \mathrm{~A}$ and $\mathrm{C} 4 \mathrm{~B}$ are components of the classical activation pathway of the complement system; they provide a surface for interaction between the antigen-antibody complex and other complement components. Coagulation factor II (thrombin) acts as a serine protease that converts soluble fibrinogen into insoluble strands of fibrin, as well as catalyzes many other coagulation-related reactions. Bearing in mind the well known cases of biological nanoparticles as the LDL and HDL, where single surface-expressed proteins dominate the biological impacts, we believe that the presence of the above described proteins could also have significant biological effect. 
The results of our study also indicated that there was a clear dependence of $\mathrm{SiO}_{2}$ NPs surface functionalization on protein identity and the NP surface characteristics. Changes in the PCs of the differently functionalized $\mathrm{SiO}_{2}$ NPs occurred with time, suggesting that the NP properties could be different at different times of biological experiment. This is an important point that should be taken under consideration for in vitro and in vivo studies in nanomedicine and nanosafety. The resulting corona created a new NP surface, which may play an important role in its interactions with cell surfaces.

It is interesting to note that a complete stripping of the PC may occur in certain environments (such as a cell phagolysosome as previously suggested [60]) causing restoration of an undecorated surface. Therefore, while NPs pass through the body, there may be serial 'refreshing' of the PC after cellular uptake by phagocytic cells. However, in neutral protein rich environment of the cytosol, at long time periods, as the hard corona is quite stable, a subsequent exposure of NPs to a new protein environment may lead to only partial displacement of the original hard corona by new molecules $[61,62]$. The relative stability of a hard corona, once formed, may suggest pre-incubating NPs intended for human use to allow at least some degree of control over the composition of the bio-nano-composite that will be present in the body. Overall, the final composition of the PC potentially depends on the environments that NP has moved through, rather than only on its current environment [62,63]. In these cases, cells 'see' a different object, thus the NP interactions with biological surfaces and receptors could be different which may affect biological responses, NP biodistribution and generally NP fate. The surface of the NP immersed in a medium containing FBS differed from the surface of the NPs in a medium of human serum. Therefore, it seems advisable to verify in vitro or in vivo studies concerning humans using human serum, rather than relying exclusively on animal serum.

\section{Conclusions}

Surface properties were found to play a significant role in determining NP behavior in different environments. Ionic strength, $\mathrm{pH}$ and biological macromolecules completely transformed the NP surface properties and potentially its biological effects. It was recognized that all of the studied $\mathrm{SiO}_{2}$ NPs tended to agglomerate/aggregate after relatively short time periods in all buffers and biological media. The aggregation depended not only on the NPs functionalization but also on their concentration and the incubation time. Aggregation was much diminished in a medium containing serum. The PC formation depended on time and NP functionalization, and varied significantly in different types of serum. The resulting corona created a new NP surface, which plays an important role in NP interactions with cell surfaces. Since the PC formation was observed to depend upon which kind of serum was applied, the human serum, rather than the animal serum, should be used while conducting in vitro or in vivo studies concerning humans.

We suspect that conflicting results of toxicity tests concerning the same nanomaterial (such as $\mathrm{SiO}_{2} \mathrm{NPs}$ ), may to some extent be due to insufficient characterization of the studied materials as well as to varied conditions used during their toxicological evaluation. Different procedures of samples preparation (different buffers/media/serum, different NPs concentration and their incubation time in certain environment) are likely to change the properties of the NPs, as shown above, and give rise to different test results. Hence, researchers must pay closer attention not only to the proper nanomaterial characterization as synthesized, but also to its characteristics under the toxicity tests conditions.

\section{Methods}

\section{Nanoparticles preparation}

Highly concentrated, spherical core/shell $50 \mathrm{~nm} \mathrm{SiO}{ }_{2} \mathrm{NPs}$ encapsulating fluorescein-isothiocyanate (FITC, $\geq 90 \%$, Fluka, Germany) were synthesized with a modified Stöber method as described previously [47,64]. The NPs surface was additionally coated with polyvinypyrrolidone (PVP, K-15, Sigma-Aldrich, Germany) and modified to generate amino and mercapto functionalities by the addition of organosilanes, such as 3-aminopropyltriethoxysilane (APTES, 98\%, Alfa Aesar, Germany) and 3-mercaptopropyltrimethoxysilane (MPTMS, Sigma-Aldrich, Germany) respectively [47,65-67].

\section{Physicochemical characterization}

The particles hydrodynamic size/size distribution and zeta potential were measured by a Zetasizer $3000 \mathrm{HSa}$, Malvern Instruments. The NPs size was determined by dynamic light scattering (DLS) technique using a He-Ne laser $(633 \mathrm{~nm})$ as light source. The stock suspension was diluted to result in a count rate of 100-500 kcps. Particle sizing measurements were performed in $10 \mathrm{~mm}$ quartz cuvettes at $25^{\circ} \mathrm{C}$. The results were expressed as average values of number, volume or intensity size distribution. The zeta potential was determined by laser Doppler electrophoresis (LDE) using a quartz capillary electrophoresis cell. All of the measurements were performed in triplicate for a single batch of NPs, and the results shown are the average of the three measurements.

The primary NPs size and shape were determined using a Phillips CM20 transmission electron microscope (TEM) working at $200 \mathrm{keV}$. For TEM analysis, stock NP suspensions were diluted $1: 100$ and $3 \mu \mathrm{L}$ were pipetted onto cobalt grids covered with polyvinyl formal/carbon (S162, Plano GmbH) and subsequently left to evaporate. 
A series of images were selected to estimate particle size/size distribution using the analySiS pro software (Olympus).

The primary NPs size and shape were additionally measured using a FEI Sirion 100 T scanning electron microscopy (SEM) working at $10 \mathrm{keV}$. For SEM analysis, $20 \mu \mathrm{L}$ stock suspensions were dried directly on the carbon adhesive pad of a SEM sample holder.

The chemical and elemental composition of NPs were examined with a PHI VersaProbe 5000 scanning X-ray photoelectron spectroscopy (XPS), using a monochromated Al K $\alpha$ X-ray beam scanned over $600 \mu \mathrm{m} \times 400 \mu \mathrm{m}$ area $(200 \mu \mathrm{m}$ diameter/50 W X-ray beam) or $1400 \mu \mathrm{m} \times$ $100 \mu \mathrm{m}(100 \mu \mathrm{m}$ diameter/100 W X-ray beam $)$ at a fixed take-off angle of $45^{\circ}$. For XPS analysis, the stock suspensions were dried on an indium surface. Spectra evaluation was performed using MultiPack-Version 9.2 software (Physical Electronics). The results in\% were derived from relative concentrations of elements and their chemical bonds from line shape analyses.

The surface chemistry measurements were performed using a time of flight-secondary ion mass spectrometry IV (ToF-SIMS, ION-TOF). The primary ion species used was $10 \mathrm{keV} \mathrm{Ga}{ }^{+}$, scanning an area of typically $150 \times 150$ $\mu \mathrm{m}^{2}$. For SIMS analysis, the stock suspensions were dried on a silicon surface.

Crystallite size and crystalline phase were evaluated by X-ray diffractometer (XRD) PANalytical EMPYREAN PIXcel with 3D Counter, operating at a voltage of $40 \mathrm{kV}$ and a current of $40 \mathrm{~mA}$ with $\mathrm{Cu} K \alpha$ and $\mathrm{K} \beta$ radiation. For XRD analysis, the stock suspensions were dried on a silicon surface.

NPs concentration was additionally analyzed with halogen moisture analyzer (HR73, Mettler Toledo). One gram of the stock solution was placed onto an analyzer plate and left for the solvent evaporation to give the wt/wt $\%$ value.

\section{Nanoparticles stability in aqueous/biological environments}

To determine the NPs stability in different environments, the NPs dispersions were prepared in sterile Millipore water (MQ), phosphate buffered saline (PBS; pH 7.4), Dulbecco's modified Eagle's medium (DMEM, Sigma-Aldrich, USA) and DMEM supplemented with $10 \%$ inactivated fetal bovine serum (FBS, Sigma-Aldrich, USA). The NPs samples were incubated at $37^{\circ} \mathrm{C}$ in a $\mathrm{CO}_{2}$ incubator for different periods of time. The NPs were analyzed with DLS, zeta potential and TEM.

\section{Sodium dodecyl sulfate polyacrylamide gel electrophoresis (SDS-PAGE)}

To investigate the NPs interactions with biomolecules, the NPs dispersions $\left(1 \times 10^{12} \mathrm{NPs} \mathrm{mL}^{-1}\right)$ were prepared in
DMEM supplemented with $10 \%$ of inactivated FBS or human serum from human male AB plasma (Sigma-Aldrich, USA). The NPs were incubated for different periods of time at $37^{\circ} \mathrm{C}$ in a $\mathrm{CO}_{2}$ incubator and centrifuged $(15 \mathrm{~min}$, $8000 \times g)$. The NPs pellets were washed three times with PBS, through gentle pipetting, to remove non-bound proteins. Bound proteins were eluted from the NPs and separated on 12\% SDS-PAGE [68] as described before [40]. A protein marker (Fisher BioReagents ${ }^{\mathrm{TM}}$ EZ-Run $^{\mathrm{TM}}$, Fisher Scientific, USA) was run on every SDS-PAGE. All of the gels were analyzed with ImageJ software [69]. The intensity of the bands was calculated for whole gels (100\%-the strongest signal/band, 0\%- pure gel/no band). All of the gels were prepared in the same way, making them possible to direct comparison.

\section{Matrix assisted laser desorption/ionization-time of flight mass spectrometry (MALDI-TOF)}

To analyze the proteins bound to the NPs, the proteins bands were dissected from the SDS-PAGE and washed three times with $50 \mathrm{mM}$ ammonium bicarbonate. The samples were treated for $20 \mathrm{~min}$ with $20 \mathrm{mM}$ dithiothreitol at $60^{\circ} \mathrm{C}$. Afterwards, the samples were left for $15 \mathrm{~min}$ in $25 \mathrm{mM}$ Iodoacetamide at $37^{\circ} \mathrm{C}$ and subsequently digested with $30 \mathrm{ng}$ trypsin/band for $4 \mathrm{~h}$ and at $37^{\circ} \mathrm{C}$.

The samples were analyzed with MALDI-TOF UltrafleXtreme (Bruker Daltonics) using a positive method operating in reflectron mode and $25 \mathrm{kV}$ acceleration voltage. The analysis was calibrated using external calibrants (Bruker Daltonics).

\section{Additional file}

Additional file 1: Zeta potential values of differently functionalized silica nanoparticles after incubation in various environments at different time.

\begin{abstract}
Abbreviations
NPS: Nanoparticles; PVP: Polyvinylpyrrolidone; FITC: Fluorescein-isothiocyanate; PC: Protein corona; FBS: Fetal bovine serum; DMEM: Dulbecco's modified Eagle's medium; MQ: Millipore water; PBS: Phosphate buffered saline; DLS: Dynamic light scattering; TEM: Transmission electron microscopy; SEM: Scanning electron microscopy; XPS: X-ray photoelectron spectroscopy; TOF-SIMS: Time of flight-secondary ion mass spectroscopy; XRD: X-ray diffraction; SDS-PAGE: Sodium dodecyl sulfate polyacrylamide gel electrophoresis; MALDI-TOF: Matrix-assisted laser desorption/ionization-time of flight.
\end{abstract}

\section{Competing interests}

The authors declare that they have no competing interests.

\section{Authors' contributions}

El, MV, SE, VFP and AD conceived and participated in the design of the study. El carried out the synthesis and characterization of the NPs, studied the NPs stability in aqueous/biological environments, and investigated interactions of the particles with proteins by SDS-PAGE and subsequently by ImageJ software. All authors were involved in critical review. All authors read and approved the final manuscript 


\section{Acknowledgements}

This study was supported by the EU 7th Framework Programme, Marie Curie Actions, Network for Initial Training NanoTOES (PITN-GA-2010-264506), www.nanotoes.eu.

The MALDI-TOF MS analyses were carried out in the Proteomics and Bioinformatics facility from the Autonomous University of Barcelona (UAB), a member of ProteoRed-ISCIII network.

The authors wish to thank Dr. Matthew Boyles and Dr. Sonia Goy López for their helpful comments and suggestions.

\section{Author details}

'Bayer Technology Services GmbH, Leverkusen 51368, Germany. 2 Department of Molecular Biology, University of Salzburg, Salzburg 5020 Austria. ${ }^{3}$ Catalan Institute of Nanotechnology (ICN), Campus UAB, Edifici CIN2, Barcelona 08193, Bellaterra, Spain

Received: 2 July 2013 Accepted: 1 November 2013 Published: 11 November 2013

\section{References}

1. Hirsch LR, Stafford RJ, Bankson JA, Sershen SR, Rivera B, Price RE, Hazle JD, Halas NJ, West JL: Nanoshell-mediated near-infrared thermal therapy of tumors under magnetic resonance guidance. Proc Natl Acad Sci USA 2003, 100:13549-13554.

2. Moghimi SM, Hunter AC, Murray JC: Nanomedicine: current status and future prospects. FASEB J 2005, 19:311-330.

3. Ravi Kumar MNV, Sameti M, Mohapatra SS, Kong X, Lockey RF, Bakowsky U, Lindenblatt G, Schmidt CH, Lehr M: Cationic silica nanoparticles as gene carriers: synthesis, characterization and transfection efficiency in vitro and in vivo. J Nanosci Nanotechnol 2004, 4:876-881.

4. Slowing II, Vivero-Escoto JL, Wu CW, Lin VS: Mesoporous silica nanoparticles as controlled release drug delivery and gene transfection carriers. Adv Drug Deliv Rev 2008, 60:1278-1288.

5. Vijayanathan $V$, Thomas T, Thomas TJ: DNA nanoparticles and development of DNA delivery vehicles for gene therapy. Biochemistry 2002, 41:14085-14094.

6. He X, Wang K, Tan W, Liu B, Lin X, He C, Li D, Huang S, Li J: Bioconjugated nanoparticles for DNA protection from cleavage. J Am Chem Soc 2003, 125:7168-7169.

7. Tapec R, Zhao JX, Tan W: Development of organic dye-doped silica nanoparticle for bioanalysis and biosensors. J Nanosci Nanotechnol 2002, 2:405-409.

8. Qhobosheane M, Santra S, Zhang P, Tan WH: Biochemically functionalized silica nanoparticles. Analyst 2001, 126:1274-1278.

9. Wang L, Tan WH: Multicolor FRET silica nanoparticles by single wavelength excitation. Nano Lett 2006, 6:84-88.

10. Zhao JX, Tapec-Dytioco R, Tan WH: Ultrasensitive DNA detection using highly fluorescent bioconjugated nanoparticles. J Am Chem Soc 2003, 125:11474-11475

11. Zhao JX, Hilliard LR, Mechery SJ, Wang Y, Bagwe RP, Jin S, Tan W: A rapid bioassay for single bacterial cell quantitation using bioconjugated nanoparticles. Proc Natl Acad Sci USA 2004, 101:15027-15032.

12. Walcarius A, Ganesan V: lon-exchange properties and electrochemical characterization of quaternary ammonium-functionalized silica microspheres obtained by the surfactant template route. Langmuir 2006, 22:469-477.

13. Han L, Sakamoto Y, Che S, Terasaki O: Insight into the defects of cage-type silica mesoporous crystals with Fd3m symmetry: TEM observations and a new proposal of 'polyhedron packing' for the crystals. Chemistry 2009, 15:818-825

14. Ow H, Larson DR, Srivastava M, Baird BA, Webb WW, Wiesner U: Bright and stable core-shell fluorescent silica nanoparticles. Nano Lett 2005 5:113-117.

15. Mailänder V, Landfester K: Interaction of nanoparticles with cells. Biomacromolecules 2009, 10:2379-2400.

16. Stark WJ: Nanoparticles in biological systems. Angew Chem Int Ed Engl 2011, 50:1242-1258.

17. Limbach LK, Bereiter $R$, Müller E, Krebs R, Gäli R, Stark WJ: Removal of oxide nanoparticles in a model wastewater treatment plant: Influence of agglomeration and surfactants on clearing efficiency. Environ Sci Technol 2008, 42:5828-5833.
18. Lynch I, Cedervall T, Lundqvist M, Cabaleiro-Lago C, Linse S, Dawson KA: The nanoparticle - protein complex as a biological entity; a complex fluids and surface science challenge for the 21 st century. Adv Colloid Interfac 2007, 134:167-174.

19. Wilhelm C, Billotey C, Roger J, Pons JN, Bacri JC, Gazeau F: Intracellular uptake of anionic superparamagnetic nanoparticles as a function of their surface coating. Biomaterials 2003, 24:1001-1011.

20. Jansch M, Stumpf $P$, Graf CM, Rühl E, Müller RH: Adsorption kinetics of plasma proteins on ultrasmall superparamagnetic iron oxide (USPIO) nanoparticles. Int J Pharm 2012, 428:125-133.

21. Aggarwal P, Hall JB, McLeland CB, Dobrovolskaia MA, McNeil SE: Nanoparticle interaction with plasma proteins as it relates to particle biodistribution, biocompatibility and therapeutic efficacy. Adv. Drug Delivery Rev 2009, 61:428-437.

22. Ge C, Du J, Zhao L, Wang L, Liu Y, Li D, Yang Y, Zhou R, Zhao Y, Chai Z, Chen $C$ : Binding of blood proteins to carbon nanotubes reduces cytotoxicity. Proc Natl Acad Sci 2011, 108:16968-16973.

23. Kittler S, Greulich C, Gebauer JS, Diendorf J, Treuel L, Ruiz L, Gonzalez-Calbet JM, Vallet-Regi M, Zellner R, Koller M, Epple M: The influence of proteins on the dispersability and cell biological activity of silver nanoparticles. J Mater Chem 2010, 20:512-518.

24. Orts-Gil G, Natte K, Drescher D, Bresch H, Mantion A, Kneipp J, Osterle W: Characterisation of silica nanoparticles prior to in vitro studies: from primary particles to agglomerates. J Nanopart Res 2011, 13:1593-1604.

25. Treuel L, Nienhaus GU: Toward a molecular understanding of nanoparticle-protein interactions. Biophys Rev 2012, 4:137-147.

26. Walczyk D, Baldelli-Bombelli F, Monopoli MP, Lynch I, Dawson KA: What the cell 'sees' in bionanoscience. J Am Chem Soc 2010, 132:5761-5768.

27. Leszczynski J: Bionanoscience: nano meets bio at the interface. Nat Nanotechnol 2010, 5:633-634

28. Moreau JW, Weber PK, Martin MC, Gilbert B, Hutcheon ID, Banfield JF: Extracellular proteins limit the dispersal of biogenic nanoparticles. Science 2007, 316:1600-1603

29. Luck M, Pistel KF, Li YX, Blunk T, Muller RH, Kissel T: Plasma protein adsorption on biodegradable microspheres consisting of Poly( $D, L$-lactide-co-glycolide), Poly(L-lactide) or ABA triblock copolymers containing Poly(oxyethylene)Influence of production method and polymer composition. J Controlled Release 1998, 55:107-120.

30. Gref R, Luck M, Quellec P, Marchand M, Dellacherie E, Harnisch S, Blunk TM, Muller RH: 'Stealth' corona core nanoparticles surface modified by polyethylene glycol (PEG): influences of the corona (PEG chain length and surface density) and of the core composition on phagocytic uptake and plasma protein adsorption. Colloids Surf B 2000, 18:301-313.

31. Gessner A, Lieske A, Paulke BR, Muller RH: Functional groups on polystyrene model nanoparticles: influence on protein adsorption. J Biomed Mater Res, Part A 2003, 65:319-326

32. Gessner A, Waicz R, Lieske A, Paulke BR, Mader K, Muller RH: Nanoparticles with decreasing surface hydrophobicities: influence on plasma protein adsorption. Int J Pharm 2000, 196:245-249.

33. Thode K, Luck M, Semmler W, Muller RH, Kresse M: Determination of plasma protein adsorption on magnetic iron oxides: sample preparation. Pharm Res 1997, 14:905-910.

34. Lundqvist M, Stigler J, Elia G, Lynch I, Cedervall T, Dawson KA: Nanoparticles size and surface properties determine the protein corona with possible implications for biological impacts. Proc Natl Acad Sci USA 2008, 105:14265-14270.

35. Cedervall T, Lynch I, Foy M, Berggård T, Donnelly SC, Cagney G, Linse S, Dawson KA: Detailed identification of plasma proteins adsorbed on copolymer nanoparticles. Angew Chem Int Ed 2007, 46:5754-5756.

36. Faunce TA, White J, Matthaei Kl: Integrated research into the nanoparticleprotein corona: a new focus for safe, sustainable, and equitable development of nanomedicines. Nanomedicine 2008, 3:859-866.

37. Casals E, Pfaller T, Duschl A, Oostingh GJ, Puntes V: Time evolution of the nanoparticle protein corona. ACS Nano 2010, 4:3623-3632.

38. Casals E, Pfaller T, Duschl A, Oostingh GJ, Puntes V: Hardening of the nanoparticle-protein corona in metal $(\mathrm{Au}, \mathrm{Ag})$ and oxide $\left(\mathrm{Fe}_{3} \mathrm{O}_{4}, \mathrm{CoO}\right.$, and $\mathrm{CeO}_{2}$ ) nanoparticles. Small 2011, 7:3479-3486.

39. Cedervall $T$, Lynch I, Lindman $S$, Berggård $T$, Thulin $E$, Nilsson $H$, Dawson KA, Linse S: Understanding the nanoparticle-protein corona using methods to quantify exchange rates and affinities of proteins for nanoparticles. Proc Natl Acad Sci USA 2007, 104:2050-2055 
40. Monopoli MP, Walczyk D, Campbell A, Elia G, Lynch I, Baldelli-Bombelli F, Dawson KA: Physico-chemical aspects of protein corona: relevance to in vitro and in vivo biological impacts of nanoparticles. J Am Chem Soc 2011, 133:2525-2534.

41. Oberdörster G, Stone V, Donaldson K: Toxicology of nanoparticles: a historical perspective. Nanotoxicology 2007, 1:2-25.

42. Drescher D, Orts-Gil G, Laube G, Natte K, Veh RW, Osterle W, Kneipp J: Toxicity of amorphous silica nanoparticles on eukaryotic cell model is determined by particle agglomeration and serum protein adsorption effects. Anal Bioanal Chem 2011, 400:1367-1373.

43. Rejman J, Zuhorn Ans IS, Oberle V, Hoekstra D: Size dependent internalization of particles via the pathways of clathrin- and caveolae-mediated endocytosis. Biochem J 2004, 377:159-169.

44. Clift MD, Bhattacharjee $S$, Brown DM, Stone $V$ : The effects of serum on the toxicity of manufactured nanoparticles. Toxicol Lett 2010, 198:358-365.

45. Tedja R, Lim M, Amal R, Marquis C: Effects of serum adsorption on cellular uptake profile and consequent impact of titanium dioxide nanoparticles on human lung cell lines. ACS Nano 2012, 6:4083-4093.

46. Mortensen NP, Hurst GB, Wang W, Foster CM, Nallathamby PD, Retterer ST: Dynamic development of the protein corona on silica nanoparticles: composition and role in toxicity. Nanoscale 2013, 5:6372-6380.

47. Izak-Nau E, Kenesei K, Murali K, Voetz M, Eiden S, Puntes VF, Duschl A, Madarász E: Interaction of differently functionalized fluorescent silica nanoparticles with neural stem- and tissue-type cells. Nanotoxicology 2013. ID:864427 DOl:10.3109/17435390.2013.864427.

48. Jiang J, Oberdöster G, Biswas P: Characterization of size, surface charge, and agglomeration state of nanoparticle dispersions for toxicological studies. J Nanopart Res 2009, 11:77-99.

49. Monopoli MP, Baldelli-Bombelli F, Dawson KA: Nanoparticle coronas take shape. Nat Nanotechnol 2011, 6:11-12.

50. Long TC, Saleh N, Tilton RD, Lowry GV, Veronesi B: Titanium dioxide (P25) produces reactive oxygen species in immortalized brain microglia (BV2): implications for nanoparticle neurotoxicity. Environ Sci Technol 2006, 40:4346-4352.

51. Kretzschmar R, Holthoff $H$, Sticher $H$ : Influence of $\mathrm{pH}$ and humic acid on coagulation kinetics of kaolinite: a dynamic light scattering study. J Colloid Interface Sci 1998, 202:95-103.

52. Burns JL, Yan YD, Jameson GJ, Biggs S: A light scattering study of the fractal aggregation behavior of a model colloidal system. Langmuir 1997, 13:6413-6420.

53. Zhang D, Wang H, Neumann O, Barhoumi A, Perham M, Hartgerink J, Wittung-Stafshede P. Halas NJ: Gold nanoparticles can induce the formation of protein-based aggregates at physiological $\mathrm{pH}$. Nano Lett 2009, 9:666-671.

54. Vroman L: Effect of adsorbed proteins on the wettability of hydrophilic and hydrophobic solids. Nature 1962, 196:476-477.

55. Mu X, Li Z, Li X, Mishra SR, Zhang B, Si Z, Yang L, Jiang W, Yan B: Characterization of protein clusters of diverse magnetic nanoparticles and their dynamic interactions with human cells. J Phys Chem C 2009, 113:5390-5395.

56. Brewer SH, Glomm WR, Johnson MC, Knag MK, Franzen S: Probing BSA binding to citrate-coated gold nanoparticles and surfaces. Langmuir 2005, 21:9303-9307.

57. Carter DC, Ho JX: Structure of Serum-Albumin. Adv Protein Chem 1994 , 45:153-203.

58. Peters T: All About Albumin: Biochemistry, Genetics, And Medical Applications. San Diego: Academic Press; 1996.

59. Dayhoff MO, Eck RV, Chang MA, Sochard MR: Atlas of Protein Sequence and Structure. Silver Spring, Maryland: National Biomedical Research Foundation; 1965.

60. Cho WS, Duffin R, Thielbeer F, Bradley M, Megson IL, MacNee W, Poland CA, Tran CL, Donaldson K: Zeta potential and solubility to toxic ions as mechanisms of lung inflammation caused by metal/metal-oxide nanoparticles. Toxicol Sci 2012, 126:469-477.

61. Gasser M, Rothen-Rutishauser B, Krug HF, Gehr P, Nelle M, Yan B, Wick P: The adsorption of biomolecules to multi-walled carbon nanotubes is influenced by both pulmonary surfactant lipids and surface chemistry. J Nanobiotechnol 2010, 8:31.

62. Lundqvist M, Stigler J, Cedervall T, Berggård T, Flanagan MB, Lynch I, Elia G, Dawson K: The evolution of the protein corona around nanoparticles: a test study. ACS Nano 2011, 5:7503-7509.
63. Schleh C, Semmler-Behnke M, Lipka J, Wenk A, Hirn S, Schäffler M, Schmid G, Simon U, Kreyling WG: Size and surface charge of gold nanoparticles determine absorption across intestinal barriers and accumulation in secondary target organs after oral administration. Nanotoxicology 2012, 6:36-46.

64. Stöber W, Fink A, Bohn EJ: Controlled growth of monodisperse silica spheres in the micron size range. J Colloid Interface Sci 1868, 26:62-69.

65. Cassidy PE, Yager BJ: A review of coupling agents as adhesion promoter. J Macromol Sci Rev Polym Technol 1971, D1:1-48.

66. Arkels B: Tailoring surfaces with silanes. Chem Technol 1977, 7:766-776.

67. Plueddeman E: Silane Coupling Agents. New York: Plenum Press; 1982.

68. Shapiro AL, Viñuela E, Maizel JV: Molecular weight estimation of polypeptide chains by electrophoresis in SDS-polyacrylamide gels. Biochem Biophys Res Commun 1967, 28:815-820.

69. Abramoff MD, Magalhães PJ, Ram SJ: Image processing with ImageJ. Biophotonics Int 2004, 11:36-42.

\section{doi:10.1186/1743-8977-10-56}

Cite this article as: Izak-Nau et al: Altered characteristics of silica nanoparticles in bovine and human serum: the importance of nanomaterial characterization prior to its toxicological evaluation. Particle and Fibre Toxicology 2013 10:56.

\section{Submit your next manuscript to BioMed Central and take full advantage of:}

- Convenient online submission

- Thorough peer review

- No space constraints or color figure charges

- Immediate publication on acceptance

- Inclusion in PubMed, CAS, Scopus and Google Scholar

- Research which is freely available for redistribution 